\title{
Miniature as a hypothetical regulatory protein of the Bursicon/Rickets signaling cascade in the wing epithelia of Drosophila melanogaster
}

\author{
O. O. Bilousov ${ }^{1,3}$, V. L. Katanaev ${ }^{1,2}$, I. A. Kozeretska ${ }^{3}$ \\ ${ }^{1}$ Department of Pharmacology and Toxicology, University of Lausanne \\ 27, Bugnon Str., CH-1005 Lausanne, Switzerland \\ ${ }^{2}$ Institute of Protein Research, Russian Academy of Sciences \\ Pushchino, Moscow Region, Russian Federation, 142290 \\ ${ }^{3}$ Educational and Scientific Center «Institute of Biology», National Taras Shevchenko University of Kyiv \\ 64/13, Volodymyrska Str., Kyiv, Ukraine, 01601 \\ iryna.kozeretska@gmail.com
}

\begin{abstract}
Soon after eclosion, epithelial cells of the Drosophila wing undergo a number of the processes due to a release of the neurohormone bursicon and its further binding to the GPCR Rickets, collectively referred to as wing maturation. Here we propose hypothetical models of the interaction between extracellular Miniature, and also Dusky, proteins and proteins responsible for triggering of the wing maturation processes in Drosophila melanogaster.
\end{abstract}

Keywords: bursicon, Rickets, Miniature, Dusky, wing maturation.

The wing of a newly emerged fly is a pale soft folded structure. Shortly after fly eclosion from a pupal case the neurohormone bursicon, synthesized in adult insect's brain at this stage of development and then released into hemolymph, triggers a number of the processes in Drosophila wing epithelial cells, which then lead to so-called wing maturation [1]. Apoptosis and epithelial-tomesenchymal transition (EMT), accompanied by the cell debris wash-out from the wing cavity with a flow of hemolymph (generated and promoted by pumping contractions of bilateral «wing hearts», which are located in the Drosophila thorax), are two pivotal acts, infallible progress of which is crucial for successful maturation of the Drosophila wing [2-4]. Fusion of the two cuticule (dorsal and ventral) sheets, produced by underlying wing epithelial cells at the previous wing morphogenesis stages, theirs subsequent melanization and sclerotization are three final accords of this symphony orchestrated by the bursicon, which ends by the formation of the expanded and flattened, sturdy and flexible flying organ of Drosophila melanogaster [1,5].

(C) Institute of Molecular Biology and Genetics, NAS of Ukraine, 2012
The neurohormone bursicon, and its Rickets receptor. Bioactive bursicon has of molecular weight of $30 \mathrm{kDa}$ and is composed of the two subunits: $\alpha$ (burs) and $\beta$ (pburs), which after cleavage of the 21-amino acid signal sequence decrease to approximately $15 \mathrm{kDa}$ each. Both bursicon moieties have the specific three-dimensional structure common for cysteine knot proteins (CKPs). It is a ring, formed by disulphide bonds established between six cysteine residues in a certain manner, two antiparallel $\beta$-strands (so-called fingers), formed by three distinct domains, and an $\alpha$-helical structure (named heel). BURS and PBURS can form homo- and heterodimers in the aqueous surrounding, due to the hydrophobic properties of their residues and, normally, bioactive bursicon is a heterodimer, but also homodimers of $\alpha$ - and $\beta$-subunits can be found in vivo with still yet unknown functions $[1,6,7]$.

The CKP family contains vertebrate glycoprotein hormones (e. g., anterior pituitary hormones follitropin, lutropin and thyrotropin, and placental chorionic gonadotropin), growth factors (e. g., nerve growth factor, transforming growth factor-beta (TGF- $\beta$ ) and plateletderived growth factor), mucins and bone morphogenetic protein antagonists. 


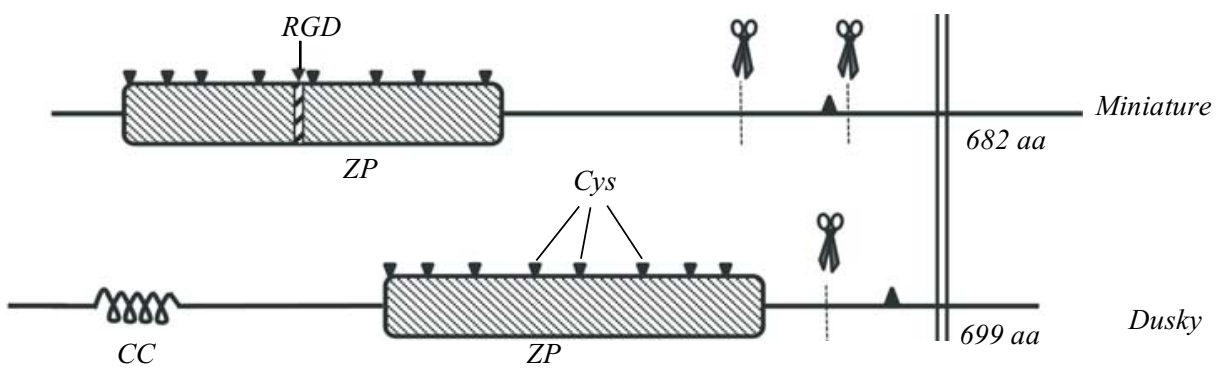

Fig. 1. Structural models of the Miniature and Dusky proteins. $Z P$ - the zona pellucida domain; $C C$ - the coiled coil region, putative glycosylation sites indicated by triangles, predicted furin-type endopeptidase cleavage sites indicated by scissors

It also necessary to say that homologs of Drosophila bursicon monomers can be found in many arthropods, mainly including species from insecta, crustacea and arachnida, and also in the echinoderm Strongylocentrotus purpuratus (purple sea urchin) [1].

The bursicon receptor has been recently identified and named Rickets. This protein belongs to a peculiar subgroup (leucine-rich repeat-containing G-protein coupled receptors - LGRs) of the great family of the Gprotein coupled receptors (GPCRs). Besides common features of GPCRs, members of this subgroup have a large N-terminal ectodomain involved in selective hormone binding. In case of the Rickets receptor, 13-18 leucine-rich repeat amino acid motifs are present in its ectodomain structure, what in turn brings this receptor to a subtype B of the LGR subgroup [6, 7].

What we should know about Miniature. The protein encoded by the miniature gene belongs to a ZP-domain containing superfamily of the proteins. It means that Miniature has rather a conservative zona pellucida (ZP)-domain with eight cysteine residues within it. What differs Miniature ZP-domain from the others (e. g., from a ZP-domain of the extracellular transmembrane protein Dusky) its localization closely to the N-terminus and, additionally, presence of the RGD-sequence (integrins binding-site) within its structure (Fig. 1). Furthermore, a predicted site of glycosylation, a transmembrane anchor and a short intracellular C-terminal tail are among interesting features of the Miniature protein, but not all: since the 32-amino acid signal sequence and predicted sites of recognition by furin-type endopeptidases near its transmembrane region are present, the processed Miniature is assumed an extracellular protein [8-10]. Moreover, ZP-domain itself serves as an extracellular matrix (ECM) polymerization module [8]. It is important to mention that ECM proteins control numerous tissue activities, including regulation of diffusion of the secreted signaling molecules such as morphogens and hormones [11].
The glance at the mechanism of the Bursicon/ Rickets signaling. Binding of bursicon to its receptor Rickets triggers apoptosis and EMT in wing epithelia of $D$. melanogaster [12] by activating of the heterotrimeric Gs-protein $[2,6]$. Upon its activation a GTPcharged Gas subunit and a G $\beta \gamma$ heterodimer are produced [13]. Then, on the one hand the Gas-GTP activates a cAMP-PKA signal cascade that in turn leads to apoptosis [2]; on the other hand the G $\beta \gamma$ seems to be responsible for the regulation of signaling branch controlling EMT and wing expansion [14]. Additionally, tissue inhibitor of metalloproteinases, caspases, integrins, and a $\beta$-catenin are implicated in Drosophila wing maturation $[15,16]$.

The great Miniature actor. At the early Drosophila wing developmental stages (between 32 and $60 \mathrm{~h}$ after puparium formation) initially columnar wing epithelial cells normally flatten and so expand in the horizontal plane, but this is not the case with miniature mutants [8], that can be a cause of the 1.5 fold reduced wing size phenotype appearance [17]. Additionally, orientation disorders of the wing blade hairs, abnormal and so incomplete adhesion of the two wing surfaces, presence of the cell debris and cuticule invaginations (visible cell outlines) in resulting space can be observed in $m i$ niature mutant adult flies $[8,18]$, even of the different species [19].

Moreover, it has recently become known that apoptosis and presumably also EMT are delayed in miniature loss-of-function mutant wings during maturation. It is notable that these effects are not due to a second site mutation, but interestingly that simultaneous disruption of the miniature and dusky (the nearest neighbor of the miniature gene, and by the way another member of the ECM, located so close that some incorporate them into the one functional complex [18]) genes induces a dramatic enhancement of, at least, the delay of apoptosis in wing epithelial cells, while mutation of the dusky 


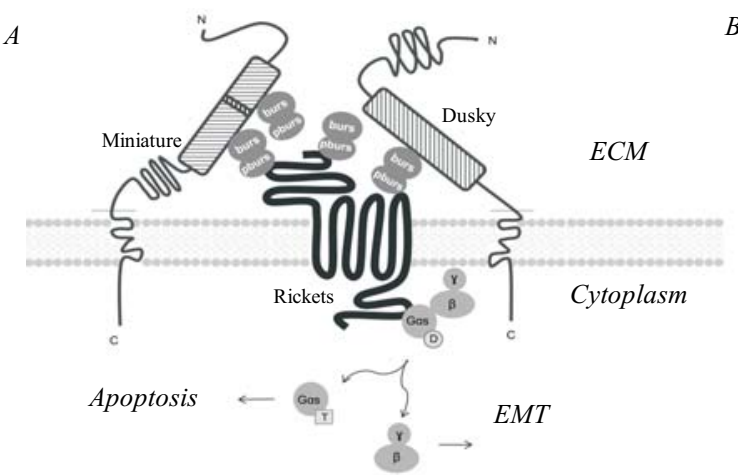

gene exclusively does not lead to any remarkable deviations from the norm.

Thus, the conclusion can be made that although Dusky is the important member of the apoptosis and EMT performance, it seems to be just a prompter of the main actor - Miniature.

Opposite to the mutant slow-down of apoptosis and presumably EMT in wing epithelia, overexpression of miniature UAS-construct by GAL4 wing drivers definitely leads to the speed-up of bursicon-induced apoptosis, but, nevertheless, not to its precocious bursicon-independent performance, which is stimulated by activation of the signaling at the level of Gas[GTP] or below. This fact forces us to mention here the last, but not the less important thing: the Miniature protein acts at the ligand or receptor levels, in accordance with scenario of the Bursicon/Rickets signaling [20].

Hypothetical regulatory models of the Bursicon/ Rickets signaling. An enormous number of the hypothesis and examples can be found, where ECM proteins have not only the structural function but are also involved in different signal transduction pathways, in which they can act as a sink (shown in Fig. 2, B) for accumulation, stabilization and activity of the soluble signal molecules, or as a solid deposit of the signal molecule precursors. Another view is that ECM proteins can act also as cofactors to some ligands or even be insoluble ligands for cognate receptors by themselves [11]. For instance, type IV collagen directly binds Dpp, a Drosophila member of the TGF- $\beta$ growth factors family [21]. Similarly, the ECM protein periostin binds and so accumulates Wnt-ligands [22].

Considering all above-mentioned hypothesis and facts, we can try to propose some hypothetical models, which can serve as specific illustrations of a possible scenario of the D. melanogaster wing maturation events, triggered by the bursicon heterodimer and its LGR-receptor Rickets, interplay regulation of which is under control of the Miniature and Dusky proteins (Fig. 2, A, B).

Notwithstanding that Miniature and Dusky both have predicted cleavage sites (Fig. 1), veraciously it is not known whether they are self-dependent components of the ECM or stay anchored on a plasma membrane.

The first model challenges the second possibility (Fig. 2, A): ZP-domain containing proteins remain associated to the plasma membrane and bind the neurohormone bursicon. Thus, defending its stability and simultaneously accumulating the signal, they support its amplification, continuity and maintenance of its stable concentrations within wing epithelial tissue by preventing the preterm washout of the bursicon with the hemolymph flow from the wing cavity during maturation; or Miniature and Dusky proteins can even act as cofactors.

According to another model, both Miniature and Dusky could be cleaved and then relatively freely diffuse into the ECM, where due to polymerization features of their ZP-domains they can form some kind of a «sink», where bursicon can be accumulated and then independently or in a complex diffuse inside the wing blade, transducing the signal further and further through the wing epithelial tissue (Fig. 2, B). An exciting verification of this hypothesis can be found in our previous paper [20].

None of these hypothetical models does exclude or contradict each other. Thus, in the first case, created complex could be cleaved off from the plasma membrane and act according to the scenario of the second model. In another case, created Miniature-Dusky-Bursicon complex can act, in turn, as a bursicon pool, thus maintaining required concentrations of the Rickets receptor 
ligand and providing continuity of the signal: main features of the first model.

Unfortunately, until there is no experimental evidence of the physical interaction between Miniature and bursicon, these proposed models still remain just hypothetical ones and so additional investigations should be provided for their perfection and/or confirmation.

\section{О. О. Білоусов, В. Л. Катанаєв, І. А. Козерецька}

Miniature як гіпотетичний білок - регулятор сигнального каскаду Bursicon/Rickets у криловому епітелії Drosophila melanogaster

Відразу після вилуплення з пупарію в крилі дрозофіли відбувається низка процесів під загальною назвою матурація, які запускаються нейрогормоном бурсиконом та його рецептором Rickets. B огляді представлено гіпотетичні моделі взаємодії білків позаклітинного матриксу Miniature, a також Dusky, які є необхідними як на ранніх стадіях формування крила, так і після вилуплення мухи, з білками, відповідальними за запуск прочесів матураиії крила y D. melanogaster. крила.

Ключові слова: бурсикон, Rickets, Miniature, Dusky, матураиія

\section{А. О. Белоусов, В. Л. Катанаев, И. А. Козереикая}

Miniature как гипотетический белок - регулятор сигнального каскада Bursicon/Rickets в крыловом эпителии Drosophila melanogaster

Сразу после вылупления из пупария в крыле дрозофиль происходит ряд прочессов под общим названием матурачия, запускаемых нейрогормоном бурсиконом и его рецептором Rickets. B обзоре представлены гипотетические модели взаимодействия белков внеклеточного матрикса Miniature, а также Dusky, необходимых как на ранних стадиях формирования крыла, так и после вылупления мухи, с белками, ответственными за запуск процесов матурации крыла у D. melanogaster.

Ключевые слова: бурсикон, Rickets, Miniature, Dusky, матураиия крыла.

\section{REFERENCES}

1. Honegger H. W., Dewey E. M., Ewer J. Bursicon, the tanning hormone of insects: recent advances following the discovery of its molecular identity // J. Comp. Physiol. A Neuroethol. Sens. Neural Behav. Physiol.-2008.-194, N 12.-P. 989-1005.

2. Kimura K., Kodama A., Hayasaka Y., Ohta T. Activation of the cAMP/PKA signaling pathway is required for post-ecdysial cell death in wing epidermal cells of Drosophila melanogaster // Development.-2004.-131, N 7.-P. 1597-1606.

3. Natzle J. E., Kiger J. A. Jr., Green M. M. Bursicon signaling mutations separate the epithelial-mesenchymal transition from programmed cell death during Drosophila melanogaster wing maturation // Genetics.-2008.-180, N 2.-P. 885-893.

4. Togel M., Pass G., Paululat A. The Drosophila wing hearts originate from pericardial cells and are essential for wing maturation // Dev. Biol.-2008.-318, N 1.-P. 29-37.

5. Johnson S. A., Milner M. J. The final stages of wing development in Drosophila melanogaster // Tissue Cell.-1987.-19, N 4.-P. 505-513.
6. Luo C. W., Dewey E. M., Sudo S., Ewer J., Hsu S. Y., Honegger H. $W$., Hsueh A. J. W. Bursicon, the insect cuticle-hardening hormone, is a heterodimeric cystine knot protein that activates $\mathrm{G}$ protein-coupled receptor LGR2 // Proc. Natl Acad. Sci. USA.2005.-102, N 8.-P. 2820-2825.

7. Van Loy T., Vandersmissen H. P., Van Hiel M. B., Poels J., Verlinden H., Badisco L., Vassart G., Vanden BroeckJ. Comparative genomics of leucine-rich repeats containing $G$ protein-coupled receptors and their ligands // Gen. Comp. Endocrinol.-2008.155, N 1.-P. 14-21.

8. Roch F., Alonso C. R., Akam M. Drosophila miniature and dusky encode ZP proteins required for cytoskeletal reorganisation during wing morphogenesis // J. Cell Sci.-2003.-116, Pt 7.-P. 1199 1207.

9. Jovine L., Darie C. C., Litscher E. S., Wassarman P. M. Zona pellucida domain proteins // Annu. Rev. Biochem.-2005.74.-P. 83-114.

10. Zhuk O. W. Kozeretska I. A., Sivolob A. V. Min-like protein of Drosophila virilis and its mutant forms: primary structure and possible functional role // Biopolym. Cell.-2008.-24, N 4.P. 286-293.

11. Hynes $R$. $O$. The extracellular matrix: not just pretty fibrils // Science.-2009.-326, N 5957.-P. 1216-1219.

12. Baker J. D., Truman J. W. Mutations in the Drosophila glycoprotein hormone receptor, rickets, eliminate neuropeptide-induced tanning and selectively block a stereotyped behavioral program // J. Exp. Biol.-2002.-205, Pt 17.-P. 2555-2565.

13. Gilman A. G. G proteins: transducers of receptor-generated signals // Annu. Rev. Biochem.-1987.-56-P. 615-649.

14. Katanayeva N., Kopein D., Portmann R., Hess D., Katanaev V. L. Competing activities of heterotrimeric G proteins in Drosophila wing maturation // PloS One.-2010.-5, N 8.-e12331.

15. Brower D. L., Jaffe S. M. Requirement for integrins during Drosophila wing development // Nature.-1989.-342, N 6247.-P. 285287.

16. Kiger J. A. Jr, Natzle J. E., Kimbrell D. A., Paddy M. R., Kleinhesselink K., Green M. M. Tissue remodeling during maturation of the Drosophila wing // Dev. Biol.-2007.-301, N 1.-P. 178-191.

17. Dobzhansky Th. The influence of the quantity and quality of chromosomal material on the size of the cells in Drosophila melanogaster // Dev. Genes Evol.-1929.-115, N 3.-P. 363-379.

18. Newby L. M., White L., DiBartolomeis S. M., Walker B. J., Dowse H. B., Ringo J. M., Khuda N., Jackson F. R. Mutational analysis of the Drosophila miniature-dusky $(m-d y)$ locus: effects on cell size and circadian rhythms // Genetics.-1991.-128, N 3.P. 571-582.

19. Kozeretska I. A., Gubenko I. S., Gorb S. N. New unusual miniature-like wing mutation in Drosophila virilis // J. Morphol.-2004.261, N 3.-P. 270-275.

20. Bilousov O. O., Kozeretska I. A., Katanaev V. L. Role of the gene Miniature in Drosophila wing maturation // genesis.-2012. DOI: $10.1002 / \mathrm{dvg}$. 22016.

21. Wang X., Harris R. E., Bayston L. J., Ashe H. L. Type IV collagens regulate BMP signalling in Drosophila // Nature.-2008.455, N 7209.-P. 72-77.

22. Malanchi I., Santamaria-Martinez A., Susanto E., Peng H., Lehr H. A., Delaloye J. F., Huelsken J. Interactions between cancer stem cells and their niche govern metastatic colonization // Nature.-2012.-481, N 7379.-P. 85-89.

Received 10.04.2012 